The Journal of Laryngology \&amp; Otology

http://journals.cambridge.org/JLO

Additional services for The Journal of Laryngology \&amp; Otology:

Email alerts: $\underline{\text { Click here }}$

Subscriptions: $\underline{\text { Click here }}$

Commercial reprints: $\underline{\text { Click here }}$

Terms of use : $\underline{\text { Click here }}$

\title{
Are the demographics for squamous cell cancer in the head and neck changing in the United Kingdom?
}

M A Hassan, V J Lund, D J Howard and A A Sacker

The Journal of Laryngology \& Otology / Volume 121 / Issue 02 / February 2007, pp 154 - 157

DOI: 10.1017/S0022215106004087, Published online: 24 October 2006

Link to this article: http://journals.cambridge.org/abstract_S0022215106004087

How to cite this article:

M A Hassan, V J Lund, D J Howard and A A Sacker (2007). Are the demographics for squamous cell cancer in the head and neck changing in the United Kingdom?. The Journal of Laryngology \& Otology, 121, pp 154-157 doi:10.1017/ S0022215106004087

Request Permissions : $\underline{\text { Click here }}$ 


\title{
Are the demographics for squamous cell cancer in the head and neck changing in the United Kingdom?
}

\author{
M A Hassan, V J Lund*, D J Howard*, A A SACKer $\dagger$
}

\begin{abstract}
Head and neck squamous cell carcinoma is well known to be more common in men than women. Smoking and alcohol are the key risk factors causing such malignancies and there are several publications which have suggested that the prevalence of these diseases is increasing more in women than in men in western countries due to increased smoking and alcohol use.

We collected our data at the Institute of Laryngology and Otology from the last 45 years and analysed the disease ratios in male to female patients in different sites within the head and neck. Our results revealed a decreasing male to female ratio, though this was not statistically significant. However, it draws attention to the increasing number of women with head and neck cancer, which may reflect their increasing use of cigarettes and alcohol.
\end{abstract}

Key words: Head and Neck Neoplasms; Carcinoma, Squamous Cell; Epidemiology, Risk Factors; Smoking; Alcohol Drinking Statistics

\section{Introduction}

Head and neck cancer is the sixth most frequently arising malignancy worldwide. Such tumours most commonly occur in the larynx, followed by the oral cavity and the pharynx. Squamous cell carcinoma is by far the most common pathological type of tumour in the upper aerodigestive tract.

Age, sex and race are important determinants of risk for head and neck squamous cell carcinomas. The median age at diagnosis is 55-65 years depending on the subsite, ${ }^{1}$ with elderly and middle aged individuals having a significantly greater risk than children or young adults. Historically, the male to female ratio for squamous cell carcinoma in the head and neck in the United Kingdom 50 years ago was $5: 1$, but the gap has now narrowed substantially to be $2: 1 .^{2}$ The incidence of head and neck squamous cell carcinoma also varies according to race, with Afro-Caribbean patients having a higher incidence in most upper aerodigestive tract sites than Caucasians. ${ }^{3}$ Within the UK higher rates are reported in Scotland and Northern Ireland than in England and Wales. The key risk factors are tobacco smoking and alcohol consumption ${ }^{4,5}$ and carcinogenesis is thought to occur in two stages: initiation and promotion. ${ }^{6}$ Tobacco is thought to be active both as an initiator (primary carcinogen) and as a promoter, while alcohol is thought to be only a promoter. According to Stevens et al., smoking alone increases the risk of squamous cell carcinoma by 5.8 times, while alcohol alone increases it by 3.6 times; together they have a synergistic effect increasing the risk by 19 times. ${ }^{8}$ A dose-dependent relationship exists between smoking and the relative risk of developing such a tumour, ranging from 2.4 for smokers of $\leq 7$ cigarettes per day to 16.4 for smokers of $\geq 25$ per day. ${ }^{9}$ Cessation of smoking leads to gradual reduction in risk by 70 per cent after 10 years. ${ }^{9}$ Others have also found a dosedependent increase in relative risk for heavy drinkers of alcohol. ${ }^{10,11}$

Manufactured tobacco smoking by men in the United Kingdom started in the 1890s, reached a peak in 1946 and has declined since. Women only started smoking in the mid 1920s and their use peaked in the late 1970 s. $^{12}$ National statistical data reported that the male to female smoking gap was 10 per cent in $1974,{ }^{13}$ but during the 1970 s and 1980s the gap narrowed and in 2002/2003 was 2 per cent. The most recent data from the Health Survey for England (2004) shows that for the first time more women (23 per cent) are smoking than men (22 per cent). ${ }^{14}$

Of those men consuming alcohol in 1978, 15 per cent were drinking moderately (11-21 units/week). This increased to 21 per cent by 1984 followed by a slight increase to 23 per cent by 1996 . Heavy drinkers ( $>21$ units/week) constituted 25 per cent of those drinking alcohol in 1978 and 27 per cent by 1996 .

From the Department of Otolaryngology, Ain Shams University, Cairo, Egypt, the *Institute of Laryngology and Otology, University College London, and the $†$ Department of Epidemiology and Public Health, University College London, UK. Accepted for publication: 23 August 2006. 
By contrast 4 per cent of women were considered moderate drinkers (8-14 units/week) in 1978, 16 per cent in 1996 and heavy drinkers (>14 units/ week) 4 per cent in 1978 and 14 per cent by $1996 .^{12}$ National statistical data also showed that alcohol consumption increased in both sexes, but much more so in women in the most recent years. ${ }^{15}$

Other risk factors include other site specific carcinogens such as nickel and chromate dust, which are associated with laryngeal and nasal carcinoma, nitrosamine in salted fish which causes nasopharyngeal carcinoma and iron deficiency anaemia, which is related to postcricoid carcinoma. In addition, viruses, such as human papilloma virus, may inactivate tumour suppressor genes such as p53 and pRb, and Epstein-Barr virus is associated with nasopharyngeal carcinoma. A positive family history also plays a role - especially in first degree relatives of patients with multiple malignancies and in Cantonese people with nasopharyngeal carcinoma. $^{9}$

Some studies have shown that the age adjusted incidence of head and neck squamous cell carcinomas has increased in females in comparison with males in Finland, ${ }^{16}$ USA, ${ }^{17,18}$ France, ${ }^{19} \mathrm{UK}^{2}$ and Italy. ${ }^{20}$ This has been related to increased smoking and alcohol intake in women in these western populations. We tested the hypothesis that these trends are also occurring in the patient population referred to a major United Kingdom head and neck unit.

\section{Materials and methods}

We analysed the head and neck cancer registry of the Professorial Unit at the Royal National Throat, Nose and Ear Hospital for all patients registered between 1960 and 2004 (45 years). From the cohort of 4454 head and neck tumours retrieved, 2170 malignant tumours, affecting the larynx, pharynx and oral cavity, were found. Non-squamous cell carcinomas were then excluded leaving 2000 cases of primary squamous cell malignancy. The patients were then divided into five time intervals of nine years each (1960-1968, 1969-1977, 1978-1986, 1987-1995 and 1996-2004) and into five sites: 1) larynx; 2) tonsil and soft palate; 3) postcricoid and cervical oesophagus; 4) oral cavity; and 5) posterior pharyngeal wall and pyriform fossa. We calculated the proportion of female cases and we then assessed this proportion for a trend in change over time. The analysis used was the Cochran-Armitage test for trend $^{21}$ implemented by Royston as ptrend in Stata (version 4). A significant overall $\chi^{2}$ test indicates that the proportion of females has changed over the five time periods and a significant trend $\chi^{2}$ signifies that this was a linear change over time.

\section{Results and analysis}

Our results showed that for all sites males were more commonly affected than females except in the postcricoid and cervical oesophagus where females were more often affected. The larynx was the most common site affected (61.9 per cent), followed by

\section{TABLE I}

SHOWING NUMBER OF FEMALES, MALES AND THE PROPORTION OF FEMALES FOR (a) CANCER OF THE LARYNX AND (b) CANCER OF THE TONSIL AND SOFT PALATE. IT ALSO SHOWS THE STATISTICAL TREND TEST FOR THE PROPORTION OF FEMALES OVER TIME

\begin{tabular}{|c|c|c|c|c|c|c|c|c|}
\hline \multirow{2}{*}{$\begin{array}{l}\text { Follow } \\
\text { up years }\end{array}$} & \multicolumn{4}{|c|}{ (a) } & \multicolumn{4}{|c|}{ (b) } \\
\hline & & q & $\sigma^{7}$ & \% (q) & & q & $\sigma^{\pi}$ & $\%(q)$ \\
\hline $1960-1968$ & $\mathrm{~L}$ & 19 & 78 & 19.6 & $\mathrm{~T}$ & 6 & 18 & 25.0 \\
\hline $1969-1977$ & A & 38 & 249 & 13.2 & $\mathrm{O}$ & 9 & 23 & 28.1 \\
\hline $1978-1986$ & $\mathrm{R}$ & 27 & 355 & 7.1 & $\mathrm{~N}$ & 12 & 23 & 34.3 \\
\hline $1987-1995$ & $\mathrm{Y}$ & 33 & 214 & 13.4 & + & 13 & 24 & 35.1 \\
\hline 1996-2004 & $\mathrm{N}$ & 38 & 187 & 16.9 & $\mathrm{~S}$ & 32 & 40 & 44.4 \\
\hline $\begin{array}{l}\text { Overall } \\
\chi^{2}(4)\end{array}$ & X & \multicolumn{3}{|c|}{$19.01, p=0.0008$} & $\mathrm{P}$ & \multicolumn{3}{|c|}{$4.41, p=0.35$} \\
\hline $\begin{array}{l}\text { Trend } \\
\qquad \chi^{2}(1)\end{array}$ & & \multicolumn{3}{|c|}{$0.18, p=0.67$} & & \multicolumn{3}{|c|}{$4.17, p=0.04$} \\
\hline
\end{tabular}

$\mathrm{TON}=$ tonsil; $\mathrm{SP}=$ soft palate

the oral cavity (11.7 per cent), the tonsil and soft palate (10 per cent), the postcricoid and cervical oesophagus (8.5 per cent) and, finally, the posterior pharyngeal wall and pyriform fossa (7.9 per cent). The most common age for developing malignancy at these sites was in the sixth and seventh decades.

For the larynx the results showed a gradually increasing male to female ratio which reached a peak in 1978-1986 (13:1) and then declining through the next 18 years to 4.9:1. Expressed as proportions, this non-linear change was confirmed by the significant overall $\chi^{2}$ test, which showed differences in the proportion of females over the five periods with a non-significant statistical linear trend test. (Table Ia).

Regarding the pharynx; the oropharyngeal results (tonsil and soft palate) showed a gradually decreasing ratio of male to females throughout the whole period with the lowest ratio reached in 1996-2004 (1.25:1). Expressed as proportions, this gradual decrease was of marginal statistical significance (Table Ib). The postcricoid and cervical oesophagus were the only sites in which females were more

TABLE II

SHOWING NUMBER OF FEMALES, MALES AND THE PROPORTION OF FEMALES FOR (a) CANCER OF THE POSTERIOR PHARYNGEAL WALL AND PYRIFORM FOSSA AND (b) CANCER OF THE POSTCRICOID AND CERVICAL OESOPHAGUS. IT ALSO SHOWS THE STATISTICAL TREND TEST FOR THE PROPORTION OF FEMALES OVER TIME

\begin{tabular}{|c|c|c|c|c|c|c|c|c|}
\hline \multirow{2}{*}{$\begin{array}{l}\text { Follow } \\
\text { up years }\end{array}$} & \multicolumn{4}{|c|}{ (a) } & \multicolumn{4}{|c|}{ (b) } \\
\hline & & ㅇ & $\sigma^{7}$ & $\%(q)$ & & q & $\sigma^{7}$ & $\%(q)$ \\
\hline $1960-1968$ & $\mathrm{P}$ & 4 & 19 & 17.4 & $\mathrm{P}$ & 20 & 9 & 69.0 \\
\hline 1969-1977 & $\mathrm{P}$ & 7 & 18 & 28.0 & $\mathrm{C}$ & 23 & 7 & 76.7 \\
\hline $1978-1986$ & $\mathrm{H}$ & 6 & 17 & 26.1 & + & 21 & 24 & 46.7 \\
\hline $1987-1995$ & + & 7 & 24 & 22.6 & $\mathrm{O}$ & 28 & 15 & 65.1 \\
\hline 1996-2004 & $\mathrm{P}$ & 16 & 40 & 28.6 & $\mathrm{E}$ & 14 & 9 & 60.9 \\
\hline $\begin{array}{l}\text { Overall } \\
\chi^{2}(4)\end{array}$ & $\mathrm{F}$ & \multicolumn{3}{|c|}{$1.30, p=0.86$} & $\mathrm{~S}$ & \multicolumn{3}{|c|}{$8.04, p=0.09$} \\
\hline $\begin{array}{l}\text { Trend } \\
\chi^{2}(1)\end{array}$ & & \multicolumn{3}{|c|}{$0.52, p=0.47$} & & \multicolumn{3}{|c|}{$0.88, p=0.35$} \\
\hline
\end{tabular}

$\mathrm{PPH}=$ posterior pharyngeal wall; $\mathrm{PF}=$ pyriform fossa; $\mathrm{PC}=$ postcricoid; OES $=$ oesophagus 
TABLE III

SHOWING NUMBER OF FEMALES, MALES AND THE PROPORTION OF FEMALES FOR (a) CANCER OF THE ORAL CAVITY AND (b) TOTAL CASES OF HEAD AND NECK CANCER. IT ALSO SHOWS THE STATISTICAL TREND TEST FOR THE PROPORTION OF FEMALES OVER TIME

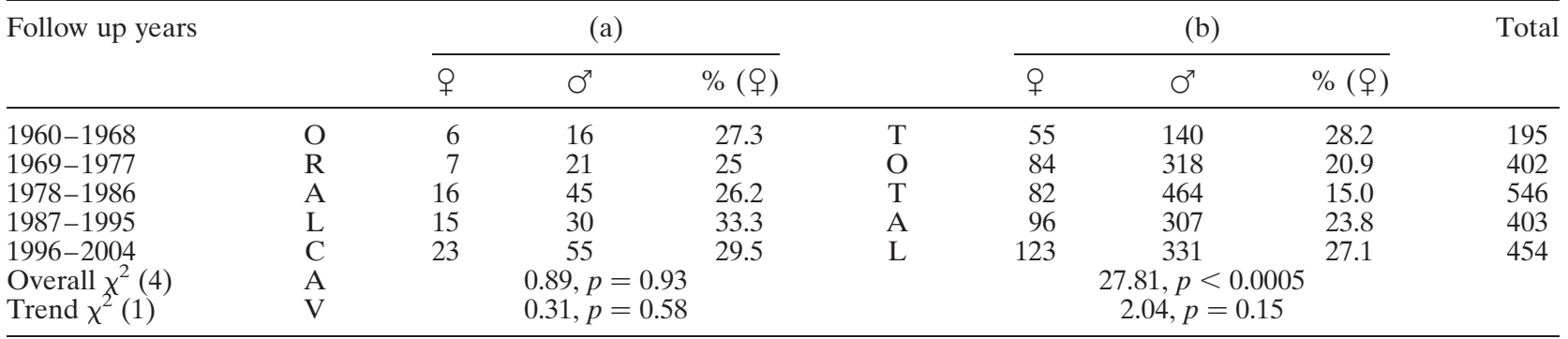

ORAL CAV $=$ oral cavity; TOTAL $=$ total head and neck squamous cell carcinoma cases

frequently affected than males in the whole study group, and here proportions fluctuated (Table IIb). For posterior pharyngeal wall and pyriform fossa cancer, the proportion of females initially increased, then declined and finally increased again (Table IIa). Finally, the oral cavity showed non-significant changes in the proportion of females (Table IIIa).

The total cases of head and neck carcinomas initially showed an increased male to female ratio which reached its maximum (5.6:1) in 1978-1986 and which then decreased again to (2.69:1) in 1996-2004. There was a highly significant change in the proportion of females over the five periods but no evidence for a linear trend over time. (Table IIIb, Figure 1).

\section{Discussion}

Changes seen in the proportion of males and females overall with head and neck cancer were consistent with the trends in tobacco smoking and alcohol consumption in the United Kingdom, ${ }^{12,13,14}$ both of which have an unquestionable carcinogenic effect in the upper aerodigestive tract. Total results were

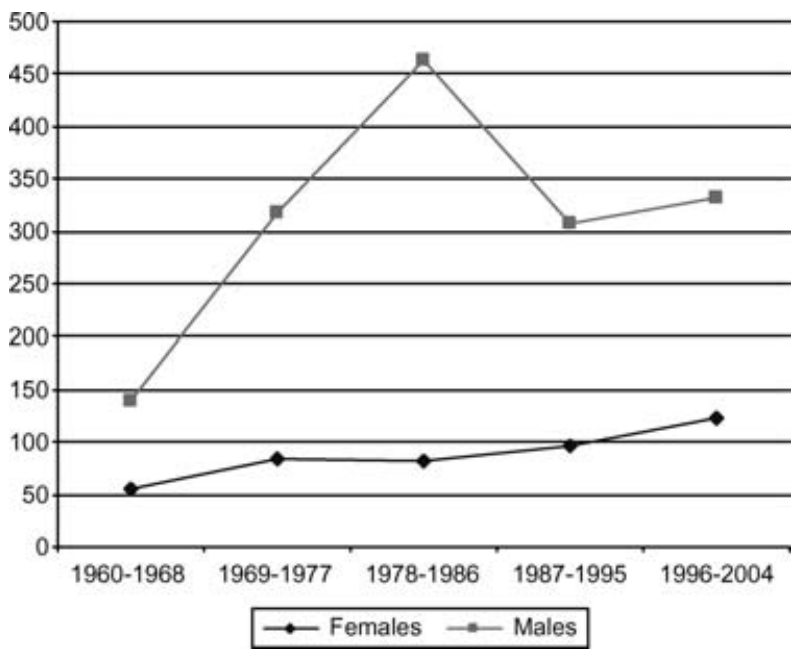

FIG. 1

This shows that males had a higher prevalence than females with head and neck squamous cell carcinoma in different decades and that the gap has decreased in the last 18 years. mostly affected by the number of cases of laryngeal cancer as it was the most common site.

- Head and neck squamous cell carcinomas affect men more commonly than women

- Smoking and alcohol are the key risk factors for head and neck squamous cell carcinoma

- The smoking of tobacco and the consumption of alcohol have increased more in women than in men since the early 1970 s in the United Kingdom

- In this paper the proportion of women with head and neck squamous cell carcinoma has increased in the last $\mathbf{1 8}$ years for cancer of the larynx and, throughout the study period, has increased for squamous cell carcinoma of the tonsil and soft palate

- The increased incidence of such malignancies occurred in the latter part of the study period

- There should be an increasing awareness of these trends and more effort made to educate women as to the dangers of smoking and drinking to excess

Changes in the male to female ratio for the larynx were different from the pharynx, and from the oral cavity, which did not show much change over time. There has been a decreasing male to female ratio in the larynx during the last 18 years $\left(\chi^{2}(1)\right.$ for trend $=14 ; p=0.0002)$ and in the pharynx throughout the study period, whereas for oropharynx the gradual decrease achieved marginal statistical significance. Thus our results agree with other studies $^{15,16,17,18,2,19}$ which have shown that head and neck squamous cell carcinomas are increasing in women more than in men. It is conjecture, but if male and female smoking patterns continue to change, the rate of head and neck squamous cell carcinoma in women may come to equal or even exceed the rate in men in a few more decades.

This study was carried out in a single institution, which might not be representative of the whole population of the United Kingdom. However, as a tertiary 
centre accepting complex head and neck cancer cases, which are selected solely by virtue of the patients' condition, there is no reason to suppose that the ratio of male to females would be biased. Detailed information of all our patients' smoking and drinking habits was not available, but is now collected for future comparative studies.

\section{Conclusion}

A review of data from our institute has shown changes in the male to female ratio for squamous cell carcinoma in some sites. This indicates a highly significant change in the proportion of females affected by head and neck squamous cell carcinomas between 1978 and 2004 although there was no evidence for a linear trend over a longer period from 1960 to 2004. In the light of this there should be increased awareness that head and neck cancer is no longer a disease primarily affecting men, and education and prevention should be directed equally to women. Despite increasing publicity with regard to smoking and alcohol, there still is insufficient emphasis on preventive measures, which could greatly reduce the incidence of head and neck cancer.

\section{References}

1 Muir C, Weiland L. Upper aerodigestive tract cancers. Cancer 1995;75(suppl 1):147-53

2 Viswanathan H, Wilson JA. Alcohol - the neglected risk factor in head and neck cancer. Clin Otolaryngol 2004;29: 295-300

3 Wasfie T, Newman R. Laryngeal carcinoma in black patients. Cancer 1988;61:167-72

4 Wynder EL, Bross IJ, Day E. A study of environmental factors in cancer of the larynx. Cancer 1956;9:86-110

5 Keane WM, Atkins JP, Wetmore R, Vidas M. Epidemiology of head and neck cancer. Laryngoscope 1981;91: 2037-45

6 Lijinsky W. Current status of experimental chemical carcinogenesis and its application to human cancer risk. Cancer Res 1979;39:2887-90

7 Schottenfeld D. Alcohol as a co-factor in the etiology of cancer. Cancer 1979;43(suppl 5):1962-6

8 Stevens MH, Gardner JW, Parkin JL, Johnson LP. Head and neck cancer survival and lifestyle change. Arch Otolaryngol 1983;109:746-9

9 Watkinson JC, Gaze MN, Wilson JA. The nature of head and neck cancer. In: Stell and Maran's Head and Neck
Surgery, 4th edn. Oxford: Butterworth-Heinemann, 2000; $1-9$

10 Maier H, Tisch M. Occupations and social habits and head and neck cancer. Curr Opin Otolaryngol Head Neck Surg 2001;9:71-3

11 Maier H, Sennewald E, Heller GF, Weidauer H. Chronic alcohol consumption - the key risk factor for pharyngeal cancer. Otolaryngol Head Neck Surg 1994;110:168-73

12 Swerdlow A, Dos Santos Silva I, Doll R. Cancer incidence and mortality in England and Wales: trends and risk factors. New York: Oxford University Press, 2001

13 Smoking: rates highest in early 20s. http://www.statistics. gov.uk/cci/nugget.asp?id=921 [29 July 2004]

14 Health Survey for England 2004. Updating of trend tables to include 2004 data. http://www.ic.nhs.uk/pubs/ hlthsvyeng2004upd [16 December 2005]

15 Drinking: drinking to excess rising among women. http:// www.statistics.gov.uk/cci/nugget.asp?id=922 [29 July 2004]

16 Mäkitie A, Pukander J, Raitiola H, Hyrynkangas K, Koivunen P, Virtaniemi J et al. Changing trends in the occurrence and subsite distribution of laryngeal cancer in Finland. European Archives Otorhinolaryngol 1999;256: 277-9

17 De Reinzo DP, Greenberg SD, Fraire AF. Carcinoma of the larynx. Changing incidence in women. Arch Otolaryngol Head Neck Surg 1991;117:681-4

18 Devesa SS, Silverman DT, Young JL Jr, Pollack ES, Brown CC, Horm JW. Cancer incidence and mortality trends among whites in United States, 1947-84. J Natl Cancer Inst 1987;79:701-70

19 Auperin A, Hill C. Epidemiology of head and neck carcinoma. Cancer Radiotherapy 2005;9:1-7

20 Capocaccia R, Micheli A, Berrino F, Gattu G, Sant M, Ruzza MR et al. Time trends of lung and larynx cancers in Italy. Int J Cancer 1994;57:154-61

21 Armitage P. Tests for Linear Trends in Proportions and Frequencies. Biometrics 1955;11:375-86

Address for correspondence:

Valerie J Lund,

Institute of Laryngology and Otology,

University College London,

330/332 Gray's Inn Road,

London WC1X 8EE,

United Kingdom.

Fax: +44(0)20 79151497

E-mail: v.lund@ucl.ac.uk

Professor V Lund takes responsibility for the integrity of the content of the paper.

Competing interests: None declared 